\title{
An Approach to the Evaluation of Program Outcomes and Consideration of Activities beyond Curriculum for Improvement of Program Outcome Attainment
}

\author{
Tauro Savita J, Dhokchawle Bharat V, Barchha Avinash B, Jain Meeta N
}

Department of Pharmaceutical Chemistry, St John Institute of Pharmacy and Research, Vevoor, Palghar East, Palghar, Maharashtra, INDIA.

\begin{abstract}
Current global scenario demands outcome based education to develop graduates with universal acceptability. Program Outcomes (POs) laid by NBA (Table 1) are the assessable components indicative of graduate potential to demonstrate competencies to practice at appropriate levels. Program Outcomes (PO) can be defined and calculated by assessment of various Course Outcomes (CO) which can further be evaluated from Learning Outcomes (LOs). Blooms Taxonomy classifies LOs into the cognitive, affective and psychomotor domains based on their level of complexity. Each LO maps to CO and hence contributes to PO. The direct and indirect assessment tools can be used to obtain course outcome attainment level. Performance at the prerequisite subject and attainment of the outcomes for previous year are the factors determining defined $\mathrm{CO}$ attainment. The attainment of Program Outcomes POs is an indicator of the graduate's potential to demonstrate competencies and practice at appropriate levels. POs are derived from the Graduate Attributes (GA) specified by the National Board of Accreditation (NBA). Curriculum designed by University is not enough for a graduate to achieve the desired level of PO attainment. $\mathrm{PO}$ attainment is calculated by considering co-curricular and extracurricular activities in addition to the curriculum specified by the affiliating University for a programmer. GA like Pharmacy Knowledge, Thinking Abilities, Planning Abilities, Professional Identity, Environment and Sustainability, Pharmacist and Society are achieved through regular curricular activities whereas other GA like Leadership Skills, Ethics, Communication and Life Long Learning can be better attained through participation in extracurricular and co-curricular activities. This paper describes a module for defining and calculating attainment of Program Outcomes. It also demonstrates how of Activities beyond Curriculum for improvement of Program Outcome attainment.
\end{abstract}

Key words: Blooms Taxonomy, Program Outcomes, Graduate Attributes, Program Educational Objectives, Co-curricular, Extracurricular.

\section{INTRODUCTION}

The efficiency and effectiveness of higher and technical education should be described in terms of learning outcomes rather than number of credits or number of hours. In a teacher-centered approach the teacher decides the content to be taught, accordingly plans the content and assesses the content that has been delivered. Whereas, in a studentcentered approach a student is expected to know and be able to perform a task, at the end of a lesson. In other words the student is aware of the outcome of a particular lesson. Learning Outcomes are statements of what a learner is expected to know, understand and/or be able to demonstrate after completion of a process of learning. A teacher should write very specific statements about observable outcomes expected of a student at the completion of every lesson as Learning Outcomes (LOs). The LOs for each module of a course are then grouped to define Course Outcomes (COs). Bloom's Taxonomy classifies LOs into three domainsCognitive, Affective and Psychomotor. Most
Submission Date: 17-04-2020; Revision Date: 17-07-2020; Accepted Date: 09-09-2020

DOI: 10.5530/ijper.54.4.183 Correspondence: Dr. Dhokchawle BV Head, Department of Pharmaceutical Chemistry, St John Institute of Pharmacy and Research, Vevoor, Manor Road, Palghar (E), Palghar-401404, Maharashtra, INDIA.

Phone: +91-02525-256486 E-mail: bharatpg@gmail.com

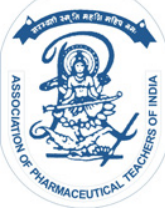

www.ijper.org 


\begin{tabular}{|c|c|c|}
\hline PO No. & Graduate Attribute & Program Outcome Description \\
\hline PO1 & Pharmacy Knowledge & $\begin{array}{l}\text { Possess knowledge and comprehension of the core and basic knowledge } \\
\text { associated with the profession of pharmacy, including biomedical sciences; } \\
\text { pharmaceutical sciences; behavioral, social and administrative pharmacy sciences; } \\
\text { and manufacturing practices }\end{array}$ \\
\hline $\mathrm{PO} 2$ & Planning Abilities & $\begin{array}{l}\text { Demonstrate effective planning abilities including time management, resource } \\
\text { management, delegation skills and organizational skills. Develop and implement } \\
\text { plans and organize work to meet deadlines }\end{array}$ \\
\hline PO3 & Problem analysis & $\begin{array}{l}\text { Utilize the principles of scientific enquiry, thinking analytically, clearly and critically, } \\
\text { while solving problems and making decisions during daily practice. Find, analyze, } \\
\text { evaluate and apply information systematically and shall make defensible decisions }\end{array}$ \\
\hline $\mathrm{PO} 4$ & Modern tool usage & $\begin{array}{l}\text { Learn, select and apply appropriate methods and procedures, resources and } \\
\text { modern pharmacy-related computing tools with an understanding of the limitations }\end{array}$ \\
\hline PO5 & Leadership skills & $\begin{array}{l}\text { Understand and consider the human reaction to change, motivation issues, } \\
\text { leadership and team-building when planning changes required for fulfillment of } \\
\text { practice, professional and societal responsibilities. }\end{array}$ \\
\hline PO6 & Professional Identity & $\begin{array}{l}\text { Understand, analyze and communicate the value of their professional roles in } \\
\text { society (e.g. health care professionals, promoters of health, educators, managers, } \\
\text { employers, employees) }\end{array}$ \\
\hline PO7 & Pharmaceutical Ethics & $\begin{array}{l}\text { Honor personal values and apply ethical principles in professional and social } \\
\text { contexts. Demonstrate behavior that recognizes cultural and personal variability } \\
\text { in values, communication and lifestyles. Use ethical frameworks; apply ethical } \\
\text { principles while making decisions and take responsibility for the outcomes } \\
\text { associated with the decisions }\end{array}$ \\
\hline PO8 & Communication & $\begin{array}{l}\text { Communicate effectively with the pharmacy community and with society at large, } \\
\text { such as, being able to comprehend and write effective reports, make effective } \\
\text { presentations and documentation and give and receive clear instructions }\end{array}$ \\
\hline PO9 & The Pharmacist and society & $\begin{array}{l}\text { Apply reasoning informed by the contextual knowledge to assess societal, } \\
\text { health, safety and legal issues and the consequent responsibilities relevant to the } \\
\text { professional pharmacy practice }\end{array}$ \\
\hline PO10 & Environment and sustainability & $\begin{array}{l}\text { Understand the impact of the professional pharmacy solutions in societal and } \\
\text { environmental contexts and demonstrate the knowledge of and need for sustainable } \\
\text { development }\end{array}$ \\
\hline PO11 & Life-long learning & $\begin{array}{l}\text { Recognize the need for and have the preparation and ability to engage in } \\
\text { independent and life-long learning in the broadest context of technological change. } \\
\text { Self-assess and use feedback effectively from others to identify learning needs and } \\
\text { to satisfy these needs on an ongoing basis }\end{array}$ \\
\hline
\end{tabular}

higher and technical education programs have syllabi that satisfy the cognitive domain of learning directly through various courses at different levels. Average contribution of curricular content is seen towards development of the psychomotor domain and poor contribution to the affective domain.

\section{Graduate Attributes (GA) and Program Outcomes (POs)}

Graduate Attributes, defined by the National Board of Accreditation (NBA), are employability characteristics expected by a recruiting organization in a candidate on successful completion of the curriculum designed for a particular program. GAs is described as Program Outcomes (POs), which are specific and measurable statements that encapsulate the skills, knowledge and behavior that students should acquire throughout the program. POs are crafted from the Program Educational Objectives (PEOs) which are to be embodied by the graduate three (3) to five (5) years after graduation and in turn are crafted from the Vision and Mission of the Institute. The level of attainment of the GAs, or in other words the POs, can be derived from the achievement of LOs which through the COs are mapped to the POs.

\section{METHOD FOR CALCULATION OF CO AND PO ATTAINMENT $^{2}$}

For a given Program, the expected attainment of the outcomes needs to be defined quantitatively. The actual attainment is derived using several assessment tools on different units of the curriculum. This paper describes a method to assess the overall attainment of POs using defined expected attainment and calculated 
actual attainment. Assessment tools are directly applied to curricular content, or we can say that these tools are applied to each course of a program, making assessment of COs the primary objective. It is therefore essential to define attainment at the level of each course itself, i.e. defined CO Attainment and then calculates its contribution to a particular PO based on its mapping. The average defined attainment of all courses that mapped to a particular PO specifies the expected level of attainment for that PO, i.e., defined PO Attainment. Evaluation using the assessment tools on courses conducted will similarly provide the calculated PO Attainment.

A module in MIS (Management Information System) has been developed to capture data related to the assessment tools and their correlation to the POs. Data can be processed at several steps to identify the contribution of the various curricular activities and thereby assess the attainment of POs.

\section{Assessment of Course Outcomes (COs)}

\section{a) Defined CO Attainment}

Generally, performance levels of students at the end of an academic year are measured in comparison to the performance at the same level by other batches of students in the previous academic years. However, most often what is not taken into consideration is the performance at the level prior to that being assessed. It is therefore essential to capture these values to create a comparable parameter for assessing performance levels over different batches of students. Since the curriculum conducted for the batches of students is the same, the Defined CO Attainment is calculated for each course in each academic year as the average of the following (Table 2)

1. Result of pre-requisite course for the students being assessed

2. Result of the previous academic year for the course being assessed

\section{b) Calculated CO Attainment}

Learning Outcomes (LOs) for every course were classified, based on their level of complexity, into the six levels of the cognitive domain as defined by Bloom's Taxonomy. Each level was assigned an expected attainment value (Table 3). The \% attainment value is the expected percentage of marks that a student should secure on attempting questions related to the particular level of Bloom's Taxonomy. The defined attainment decreases with the increasing complexity of the learning outcome. Assessment of the attainment of LOs is done
Table 2: Defined Course Outcome attainment.

\begin{tabular}{|c|c|c|}
\hline $\begin{array}{c}\text { Course being } \\
\text { Assessed }\end{array}$ & $\begin{array}{c}\text { Anatomy } \\
\text { Physiology } \\
\text { Pathophysiology I }\end{array}$ & $\begin{array}{c}\text { Anatomy } \\
\text { Physiology } \\
\text { Pathophysiology II }\end{array}$ \\
\hline $\begin{array}{c}\text { Result of the } \\
\text { previous academic } \\
\text { year for the course } \\
\text { being assessed }\end{array}$ & $75.52 \%$ & $80.26 \%$ \\
\hline $\begin{array}{c}\text { Pre-requisite } \\
\text { subject }\end{array}$ & Biology at Std. XII & $\begin{array}{c}\text { Anatomy Physiology } \\
\text { Pathophysiology I }\end{array}$ \\
\hline $\begin{array}{c}\text { Result of pre- } \\
\text { requisite course for } \\
\text { the students being } \\
\text { assessed }\end{array}$ & $85.56 \%$ & $75.52 \%$ \\
\hline $\begin{array}{c}\text { Defined CO } \\
\text { Attainment }\end{array}$ & $80.54 \%$ & $77.89 \%$ \\
\hline
\end{tabular}

by mapping the questions asked in a written exam (the formal evaluation method for any program) to the level of Bloom's Taxonomy.

For assigning the percentage for each bloom taxonomy level as $70 \%$ is awarded as First Class with Distinction, we chose this as the highest level. Followed by $10 \%$ intervals for others.

The quantitative assessment for each LO is mapped to the respective $\mathrm{CO}$. The average of all contributions from the various assessment tools is taken as the Calculated CO Attainment (Table 4).

\section{Assessment of Program Outcomes (POs)}

Each CO maps to POs with strong (100\% Define and Calculated PO Value), medium ( $80 \%$ of Define and Calculated PO Value) or weak (60\% of Define and Calculated PO Value) contributions. Parallel calculations were done for evaluating the contribution of COs, Courses and Semesters sequentially using the 'Defined CO Attainment' value (Table 5) and the 'Calculated CO Attainment' value (Table 6).

Following calculations were done for defined $\mathrm{CO}$ and calculated $\mathrm{CO}$ for each Course Outcome of a course and mapped to the respective PO.

The last row provides the average attainment of each PO for this Course. Similar calculations were done for all courses of the semester and the average attainments were tabulated as below.

The last row provides the average attainment of each PO for this Semester. Similar calculations were done for all the semesters and the average attainments were tabulated as in Table 7 and 8 . 


\begin{tabular}{|c|c|c|c|}
\hline Level & Description & $\begin{array}{l}\text { Expected Attainment } \\
\text { (EA) }\end{array}$ & Assessment \\
\hline Knowledge & Recalling or remembering & $70 \%$ & \multirow{6}{*}{$\begin{array}{l}\text { Example for a Knowledge based question } \\
\text { No. of students securing } \geq E A \text { of the maximum } \\
\text { marks for that question } \\
\text { No. of students attempting that question }\end{array}$} \\
\hline Understanding & $\begin{array}{l}\text { Understanding something that has been } \\
\text { communicated }\end{array}$ & $60 \%$ & \\
\hline Application & $\begin{array}{l}\text { Using a general concept to solve } \\
\text { problems in a particular situation; }\end{array}$ & $50 \%$ & \\
\hline Analysis & $\begin{array}{l}\text { Focus on identification of parts or } \\
\text { analysis of relationships between parts, }\end{array}$ & $40 \%$ & \\
\hline Evaluation & judging with the use of definite criteria & $30 \%$ & \\
\hline Creativity & $\begin{array}{l}\text { Creating something new by putting parts } \\
\text { of different ideas together }\end{array}$ & $20 \%$ & \\
\hline
\end{tabular}

\begin{tabular}{|c|c|c|c|c|c|c|c|c|c|c|}
\hline \multirow{3}{*}{ Course 01} & \multicolumn{8}{|c|}{ Direct Assessment } & \multirow{3}{*}{$\begin{array}{c}\text { In Direct } \\
\text { Assessment } \\
\begin{array}{c}\text { Course Exit } \\
\text { Form }\end{array}\end{array}$} & \multirow{3}{*}{$\begin{array}{c}\text { Total } \\
\text { Assessment }\end{array}$} \\
\hline & \multirow{2}{*}{$\begin{array}{l}\mathrm{A} \\
1\end{array}$} & \multicolumn{5}{|c|}{ Quiz } & \multirow{2}{*}{ PT } & \multirow{2}{*}{ ESE } & & \\
\hline & & 1 & 2 & 3 & 4 & 5 & & & & \\
\hline CO 1 & 92 & 89.00 & - & - & - & & 85.53 & 69.93 & 66.35 & 80.56 \\
\hline $\mathrm{CO} 2$ & 89 & & 75.00 & - & - & 76.60 & 76.63 & 69.93 & 54.25 & 74.29 \\
\hline $\mathrm{CO} 3$ & - & - & - & 93.33 & - & - & 72.32 & 69.93 & 45.52 & 70.27 \\
\hline $\mathrm{CO} 4$ & - & - & - & - & - & - & - & 69.93 & 70.12 & 76.57 \\
\hline
\end{tabular}

(A-Assignment, PT-Internal Test, ESE-End Semester Exam)

\begin{tabular}{|c|c|c|c|c|c|c|c|c|c|c|c|}
\hline & P01 & $\mathrm{PO} 2$ & $\mathrm{PO} 3$ & PO4 & PO5 & PO6 & PO7 & P08 & PO9 & P010 & P011 \\
\hline $\mathrm{CO} 1$ & 80.54 & - & - & - & - & 64.43 & - & - & - & 48.32 & 64.43 \\
\hline $\mathrm{CO} 2$ & 80.54 & - & - & - & - & 64.43 & - & - & - & 48.32 & 64.43 \\
\hline $\mathrm{CO} 3$ & 80.54 & - & - & 48.32 & - & 64.43 & - & - & - & 48.32 & 64.43 \\
\hline $\mathrm{CO} 4$ & 80.54 & - & - & 64.43 & - & 64.43 & - & - & - & 48.32 & 64.43 \\
\hline Course 1 & 80.54 & 0 & 0 & 56.37 & 0 & 64.43 & 0 & 0 & 0 & 48.32 & 64.43 \\
\hline
\end{tabular}

\begin{tabular}{|c|c|c|c|c|c|c|c|c|c|c|c|}
\hline & P01 & PO2 & $\mathrm{PO} 3$ & PO4 & PO5 & PO6 & PO7 & PO8 & PO9 & P010 & P011 \\
\hline Co1 & 80.56 & - & - & - & - & 64.44 & - & - & - & 48.33 & 64.44 \\
\hline $\mathrm{CO} 2$ & 74.29 & - & - & - & - & 59.43 & - & - & - & 44.57 & 59.43 \\
\hline $\mathrm{CO} 3$ & 70.27 & - & - & 42.16 & - & 56.21 & - & - & - & 42.16 & 56.21 \\
\hline $\mathrm{CO} 4$ & 76.57 & - & - & 61.25 & - & 61.25 & - & - & - & 45.94 & 61.25 \\
\hline Course 1 & 75.42 & 0 & 0 & 51.70 & 0 & 60.33 & 0 & 0 & 0 & 45.25 & 60.33 \\
\hline
\end{tabular}

\begin{tabular}{|c|c|c|c|c|c|c|c|c|c|c|c|}
\hline & P01 & PO2 & $\mathrm{PO} 3$ & PO4 & PO5 & PO6 & PO7 & PO8 & PO9 & P010 & P011 \\
\hline Course 1 & 80.54 & - & - & 56.37 & & 64.43 & - & - & - & 48.32 & 64.43 \\
\hline Course 2 & 78.89 & 45.23 & 53.54 & 0 & 58.75 & - & - & & 65.62 & 63.21 & - \\
\hline Course 3 & 79.80 & - & - & 60.67 & 73.72 & 56.54 & 68.83 & 54.21 & & 54.25 & 56.34 \\
\hline Course 4 & 83.24 & - & - & 63.78 & 45.65 & - & - & - & - & 72.42 & - \\
\hline Semester 1 & 80.61 & 45.23 & 56.21 & 60.27 & 59.37 & 60.48 & 64.87 & 54.21 & 70.57 & 59.55 & 60.38 \\
\hline
\end{tabular}




\section{Assessing the Attainment of Program Outcomes}

Calculated PO Attainments and Defined PO Attainments are derived from Calculated CO Attainment and Defined CO Attainment respectively (Table 9 and 10). Ratio of the Calculated PO Attainment to the Defined PO Attainment will gave us an assessment of PO Attainment (Table 11).

\section{IMPORTANCE OF CO-CURRICULAR AND EXTRACURRICULAR ACTIVITIES}

Based on the assessment of POs as per above method it is observed that Some POs are not sufficiently mapped by the course outcomes of the curriculum hence they need to be attained through conduction of allied activities. Academic calendar of the program should be planned such that all the activities are evenly distributed and activities conducted should be mapped to deficient POs to improve their attainment. For the development of the various facets of personality, curriculum must be supplemented with various co-curricular and extracurricular activities (allied activities). These allied activities affect all domains like cognitive, emotional, social and cultural. Co-curricular activities are more focused on cognitive aspects, thereby helping in intellectual development and allow students to blend aspects of their academic learning into personal actions. Competitiveness, excellence, creativity and enthusiasm are few of the outcomes achieved through extra-curricular activities. As per some of the research findings it was observed that the students who were assessed as good candidates had participated in the other than curriculum activities. Results of various surveys have also indicated that the amount of

\begin{tabular}{|c|c|c|c|c|c|c|c|c|c|c|c|}
\hline & P01 & $\mathrm{PO} 2$ & $\mathrm{PO} 3$ & PO4 & PO5 & PO6 & PO7 & P08 & PO9 & P010 & P011 \\
\hline Course 1 & 75.42 & 0 & 0 & 51.7 & 0 & 60.33 & 0 & 0 & 0 & 45.25 & 60.33 \\
\hline Course 2 & 73.73 & 41.20 & 52.14 & 0 & 51.723 & 0 & 74.2 & 0 & 61.62 & 62.22 & 0 \\
\hline Course 3 & 78.19 & 0 & 0 & 57.63 & 74.72 & 52.84 & 64.23 & 52.21 & 0 & 54.33 & 57.13 \\
\hline Course 4 & 80.19 & 0 & 54.83 & 61.74 & 43.56 & 0 & 55.54 & 0 & 71.53 & 71.12 & 0 \\
\hline Semester 1 & 76.88 & 41.20 & 53.49 & 57.02 & 56.67 & 56.59 & 64.66 & 52.21 & 66.58 & 58.23 & 58.73 \\
\hline
\end{tabular}

\begin{tabular}{|c|c|c|c|c|c|c|c|c|c|c|c|}
\hline & P01 & $\mathrm{PO} 2$ & $\mathrm{PO} 3$ & PO4 & PO5 & PO6 & PO7 & P08 & PO9 & P010 & P011 \\
\hline Semester 1 & 80.61 & 45.23 & 56.21 & 60.27 & 59.37 & 60.48 & 64.87 & 54.21 & 70.57 & 59.55 & 60.38 \\
\hline Semester 2 & 84.58 & 47.56 & 51.45 & 79.94 & 55.24 & 65.45 & 62.32 & 66.23 & 69.23 & 65.62 & 45.25 \\
\hline Semester 3 & 83.23 & 53.24 & 59.64 & 78.18 & 50.12 & 62.23 & 64.56 & 56.25 & 82.45 & 56.14 & 70.54 \\
\hline Semester 4 & 79.94 & 60.28 & 56.25 & 82.45 & 56.14 & 70.12 & 68.87 & 52.23 & 65.54 & 87.27 & 69.89 \\
\hline Semester 5 & 78.18 & 55.64 & 75.87 & 59.54 & 58 & 79.48 & 79.94 & 51.19 & 72.23 & 48.89 & 75.87 \\
\hline Semester 6 & 82.45 & 49.54 & 70.14 & 55.64 & 51.24 & 75.24 & 78.18 & 60.16 & 59.54 & 58 & 70.14 \\
\hline Semester 7 & 89.45 & 62.61 & 78.48 & 66.67 & 49.25 & 71.65 & 82.45 & 62.45 & 55.64 & 51.24 & 74.23 \\
\hline Semester 8 & 90.19 & 50.50 & 70.12 & 63.62 & 52.63 & 69.23 & 84.24 & 65.62 & 80.18 & 85.25 & 82.14 \\
\hline Program & 83.58 & 53.08 & 64.77 & 68.29 & 54.00 & 69.24 & 73.18 & 58.54 & 69.42 & 64.00 & 68.56 \\
\hline
\end{tabular}

\begin{tabular}{|c|c|c|c|c|c|c|c|c|c|c|c|}
\hline & P01 & $\mathrm{PO} 2$ & $\mathrm{PO} 3$ & PO4 & PO5 & PO6 & PO7 & PO8 & PO9 & P010 & P011 \\
\hline Semester 1 & 76.88 & 40.25 & 51.23 & 56.23 & 54.12 & 51.23 & 61.23 & 52.89 & 65.23 & 54.23 & 56.31 \\
\hline Semester 2 & 82.35 & 45.54 & 50.21 & 76.25 & 56.23 & 63.23 & 60.23 & 65.23 & 68.75 & 64.23 & 46.23 \\
\hline Semester 3 & 79.54 & 51.26 & 55.62 & 75.32 & 49.23 & 60.24 & 61.78 & 55.96 & 81.85 & 54.28 & 69.78 \\
\hline Semester 4 & 80.25 & 58.23 & 55.13 & 80.25 & 54.14 & 68.21 & 64.59 & 50.89 & 64.23 & 85.67 & 65.23 \\
\hline Semester 5 & 74.13 & 52.21 & 74.21 & 57.23 & 55.32 & 76.23 & 79.85 & 50.47 & 70.23 & 46.17 & 74.23 \\
\hline Semester 6 & 80.26 & 47.26 & 69.25 & 54.15 & 49.13 & 72.13 & 75.23 & 59.55 & 54.23 & 56.32 & 67.25 \\
\hline Semester 7 & 85.53 & 60.21 & 76.23 & 65.89 & 47.23 & 70.58 & 80.24 & 61.25 & 52.23 & 50.78 & 70.98 \\
\hline Semester 8 & 88.25 & 48.15 & 69.25 & 61.78 & 50.27 & 70.96 & 82.35 & 64.98 & 80.09 & 83.23 & 80.37 \\
\hline Program & 80.90 & 50.39 & 62.64 & 65.89 & 51.96 & 66.60 & 70.69 & 57.65 & 67.11 & 61.86 & 66.30 \\
\hline
\end{tabular}




\begin{tabular}{|c|c|c|c|c|c|c|c|c|c|c|c|}
\hline \multicolumn{10}{c|}{ Table 11: Assessment of PO Attainment for a Program. } \\
\hline & P01 & PO2 & PO3 & PO4 & PO5 & PO6 & PO7 & P08 & P09 & PO10 & P011 \\
\hline Calculated & 80.90 & 50.39 & 62.64 & 65.89 & 51.96 & 66.60 & 70.69 & 57.65 & 67.11 & 61.86 & 66.30 \\
\hline Defined & 83.58 & 53.08 & 64.77 & 68.29 & 54.00 & 69.24 & 73.18 & 58.54 & 69.42 & 64.00 & 68.56 \\
\hline Assessment & 96.76 & 94.93 & 96.71 & 96.49 & 96.22 & 96.19 & 96.60 & 98.48 & 96.67 & 96.66 & 96.70 \\
\hline
\end{tabular}

\begin{tabular}{|c|c|c|c|}
\hline \multicolumn{4}{|c|}{ Table 12: Extracurricular and Cocurriclular activities with PO's mapped. } \\
\hline Sr. No & Name of Activity & Mapped to PO & Attributes Imparted \\
\hline 01 & Poster presentation & $2,8,11$ & Creativity, Presentation skill \\
\hline 02 & Project or model competition & 10,11 & Thinking ability, Innovation \\
\hline 03 & Oral Presentation & 6,8 & Knowledge, Communication \\
\hline 04 & Debate & 5,8 & Teadership skills, Team work \\
\hline 05 & Drama & $5,7,8$ & Team wommunication \\
\hline
\end{tabular}

\begin{tabular}{|c|c|c|c|}
\hline$\underset{\text { Cevels }}{\text { Criteria/Attributes }} \downarrow$ & Low/1 & Medium/3 & $\mathrm{High} / 5$ \\
\hline $\begin{array}{l}\text { Relevance and depth of content } \\
\text { to theme }\end{array}$ & $\begin{array}{l}\text { Poor literature survey, } \\
\text { inappropriate use of resources, } \\
\text { overall content with poor } \\
\text { relevance }\end{array}$ & $\begin{array}{l}\text { Moderate literature survey, } \\
\text { fairly good use of resources, } \\
\text { overall content relevant }\end{array}$ & $\begin{array}{l}\text { Excellent use of resources } \\
\text { with in-depth literature survey, } \\
\text { overall content highly relevant }\end{array}$ \\
\hline $\begin{array}{l}\text { Communication Skills: } \\
\text { - } \quad \text { Clarity } \\
\text { - } \quad \text { Audibility } \\
\text { - } \quad \text { Delivery } \\
\text { Time } \\
\text { Management }\end{array}$ & $\begin{array}{l}\text { Poor clarity, inaudible, } \\
\text { language errors, poor time } \\
\text { management }\end{array}$ & $\begin{array}{l}\text { Moderately clear, audible, } \\
\text { acceptable language, } \\
\text { reasonable time management }\end{array}$ & $\begin{array}{l}\text { Extremely clear, very audible, } \\
\text { good command over the } \\
\text { language, perfect time } \\
\text { management }\end{array}$ \\
\hline $\begin{array}{l}\text { Body Language: } \\
\text { - } \quad \text { Posture and confidence } \\
\text { - } \quad \text { Eye Contact }\end{array}$ & $\begin{array}{l}\text { Not facing the audience at all, } \\
\text { Nervous, no eye contact }\end{array}$ & $\begin{array}{l}\text { Occasionally eye contact, less } \\
\text { confident }\end{array}$ & $\begin{array}{l}\text { Good eye contact and } \\
\text { engaging the audience by } \\
\text { delivering with confidence }\end{array}$ \\
\hline $\begin{array}{l}\text { Interaction with audience / } \\
\text { defending content }\end{array}$ & $\begin{array}{l}\text { Unable to answer the questions } \\
\text { put forth by audience and } \\
\text { judges. }\end{array}$ & $\begin{array}{l}\text { Able to answer a few questions } \\
\text { put forth by audience and } \\
\text { judges }\end{array}$ & $\begin{array}{l}\text { Satisfactorily answered } \\
\text { maximum questions. }\end{array}$ \\
\hline
\end{tabular}

\begin{tabular}{|c|c|c|c|c|c|}
\hline \multicolumn{7}{|c|}{ Table 14: Responses and calculation of average attainment b. } \\
\hline $\begin{array}{c}\text { Sr. } \\
\text { No. }\end{array}$ & Criteria & Low/1 & Medium/3 & High/5 & \% Attainment \\
\hline 1 & Relevance and depth of content to theme & 19 & 22 & 11 & 53.84 \\
\hline 2 & Communication Skills & 17 & 20 & 15 & 58.46 \\
\hline 3 & Body Language & 9 & 25 & 18 & 66.92 \\
\hline 4 & Interaction with audience / defending content & 17 & 27 & 08 & 53.07 \\
\hline & Average attainment (b) & & & & 58.07 \\
\hline
\end{tabular}

\begin{tabular}{|c|c|}
$\begin{array}{c}\text { Table 15: Responses of participants for question } \mathbf{1} \text { of } \\
\text { feedback survey from participants. }\end{array}$ \\
\hline Rating value & Number of ratings \\
\hline 1 & 9 \\
\hline 2 & 11 \\
\hline 3 & 13 \\
\hline 4 & 9 \\
\hline 5 & 10 \\
\hline
\end{tabular}

participation in the co-curricular and extra-curricular activities was positively related to academic achievement. All these reports indicate the importance of these allied activities in addition to the curriculum; ${ }^{3}$

1. Co-curricular and Extracurricular activities develop competitive attitude amongst the students and increase efficiency in performance.

2. It also imparts the ability of innovative thinking and improves the skills of students. 
3. It develops the sense of responsibility and makes the realization of duties towards family and society.

4. It imbibes the ability of organizing events and nurtures the managerial and leadership qualities.

5. It provides an opportunity to interact with people and to do self-assessment.

6. It also develops the ability to handle the critical situations and to take right decision.

7. It improves communication skill and grooms the personality

8. It aids to accomplish the personal goals and hobbies.

\section{Types of Co-curricular and Extracurricular Activity}

These activities can be classified as;

1. Study or survey related activities like model competition and field survey.

2. Physical development activities like sports.

3. Cultural development activities like drama and shows.

4. Social welfare activities like cleanliness and blood donation drive.

\section{Mapping of Extracurricular and Co-Curricular activities to $\mathrm{POs}^{4,5}$}

Most of the extracurricular and Co-curricular activities develop several important characteristics in the learner Some of the possible benefits are handling the examination stress, creative thinking, leadership skills, improved academic performance and realization of social responsibility. These activities are mapped to one or more POs and contribute to their attainment. The Table 12 describes mapping of these activities to PO and attributes imparted through them.

\section{Illustration of Po Attainment for Co-curricular Activity $^{6}$ \\ Poster Presentation}

Poster presentation involves preparation, display and explanation of poster based on provided theme. In this activity the participants are evaluated for qualities like knowledge about topic, teamwork, presentation skill, communication skill and creativity. This activity maps to PO 2, 8 and 11 as given in Table 12. Attainment for any extracurricular or co-curricular activity can be calculated by considering three factors;

1. Number of participants

2. Evaluation of participants by expert/judges using rubrics

3. Feedback from participants to assess knowledge gained through the activity

The calculation of PO attainment through poster presentation is exemplified below:
Consider that the poster presentation activity is conducted for the class of 60 students on the topic of Green chemistry. For this activity PO attainment will be calculated as

1. If out of 60 students, 52 participated in the activity, attainment value (a) from the participation will be, a $=54 / 60 * 100=90 \%$

2. Participants were evaluated as per rubrics given in Table 13 and 14 on the scale of 1,3 and 5 to give attainment value $b$.

The formula to calculate attainment value for any criteria of rubric is as given below:

Attainment for Criteria 1 of rubric $=\{(1 \times$ Number of students who got response 1) $+(3 \times$ Number of students who got response 3$)$ $+(5 \times$ Number of students who got response 5) $/ 5 \times$ Total no. of responses\} $\times 100$

The average attainment (b) is found to be 58.07

1. Feedback survey was taken from 52 participants to get the attainment value (c). They rated the feedback questionnaire on a scale of 1 - 5 (1-Poor, 2-Average, 3-Good, 4-Very Good, 5-Excellent)

The formula to calculate attainment value for any question is as given below:

Attainment for Q1 $=\{(1 \times$ Number of students who gave response 1$)+(2 \times$ Number of students who gave response $2)+(3 \times$ Number of students who gave response 3$)+$ $(4 \times$ Number of students who gave response 4$)+(5 \times$ Number of students who gave response $5) / 5 \times$ Total no. of responses $\}$ $\times 100$

Attainment value for question 1 was calculated by using responses given by 52 participants.

Attainment for Q1 $=60 \%$, Average attainment (c) for 10 questions of feedback survey was obtained $68.36 \%$ (Table 15).

Total PO attainment was taken as average of attainment value a $(90 \%)$, b $(58.07 \%)$ and c $(68.36 \%)$. Average attainment vale for poster presentation was found to be $72.14 \%$. This attainment value will be added to mapping 
POs (2, 8 and 11) for calculation of PO attainment of particular semester.

\section{CONCLUSION}

PO Attainment indicates the level of achievement of GAs in graduates. PO Attainment comparisons can be done at every stage from Course Outcomes at each semester till completion of program. The advantage is identification of weak contributions so that corrective actions can be taken at appropriate stages. Extracurricular and co-curricular activities have very important role in overall development of the students. It was observed that some of the POs are not satisfactorily attained by only the curriculum. The expected PO attainment value was obtained by planning activities like poster presentation in the academic calendar. The overall PO attainment value was improved after adding attainment values of these supplementary activities. Proper distribution of the activities amongst all the semesters and their mapping to all the deficient POs will help to achieve the expected PO attainment. Graduates will improve in leadership, communication, teamwork and ethics along with pharmacy knowledge and thinking abilities. This will help graduates to become universally employable and institute will successfully achieve their Program Educational objectives, Vision and Mission.

\section{ACKNOWLEDGEMENT}

The authors are grateful for the assistance and encouragement from Mr. Albert W. D'Souza, Chairman and Members of Aldel Education Trust, Borivali. Thanks are due to the MIS team at St. John Technical Campus, Palghar for their support in this work.

\section{CONFLICT OF INTEREST}

The authors declare that there is no conflict of interest.

\section{ABBREVIATIONS}

Pos: Program Outcomes; GAs: Graduate Attributes; Cos: Course Outcomes; Los: Learning Outcomes; NBA: National Board of Accreditation; PEOs: Program Educational Objectives; MIS: Management Information System.

\section{REFERENCES}

1. National Board of Accreditation. Self-Assessment Report (SAR) Manual undergraduate Pharmacy Program. 2016;38.

2. Tauro SJ, Dhokchawle BV, Barchha AB, Jain MN. Approaches to improve Programme Outcome Attainment. Proceedings of $3^{\text {rd }}$ World Summit on Accreditation. New Delhi, India. 2016;19-20.

3. Eric GB, Lisa AL. Preprofessional Curriculum in Preparation for Doctor of Pharmacy Educational Programs. American Journal of Pharmaceutical Education. 2009;73(8):1-14.

4. Vicky G, Sheena B, Klaus K. Thinking strategically about employability and graduate attributes; universities and enhancing learning beyond syllabus. Quality Assurance Agency for Higher Education. 2012;66:1-6.

5. Alan SS, Andrew L. Improving the Learning of Graduate Attributes in the Curriculum: a Case-Study in IT Management. Proc. $12^{\text {th }}$ Australasian Computing Education Conference; Brisbane, Australia. 2010;05-7.

6. Dhokchawle BV, Tauro SJ, Barchha AB, Chaturvedi P. Activities beyond Curriculum for improvement of Program Outcome attainment. Proceedings of $4^{\text {th }}$ World Summit on Accreditation; New Delhi, India. 2018;07-9.

\section{SUMMARY}

The attainment of Program Outcomes is an indicator of the graduate's potential to demonstrate competencies and practice at appropriate levels. Programme Outcomes are derived from the Graduate Attributes (GA) specified by the National Board of Accreditation. PO attainment is calculated by considering cocurriclular and extracurricular activities in addition to the curriculum specified by the affiliating University for a programme. Graduate attributes like pharmacy knowledge, thinking abilities, planning abilities, professional identity, environment and sustainability and pharmacist and society are achieved through regular curricular activities whereas several other Graduate Attributes like leadership skills, ethics and communication can be better attained through participation in extracurricular and cocurriclular activities which involve such aspects. The current review describes the mapping of those activities to graduate attributes and their contribution to PO attainment.

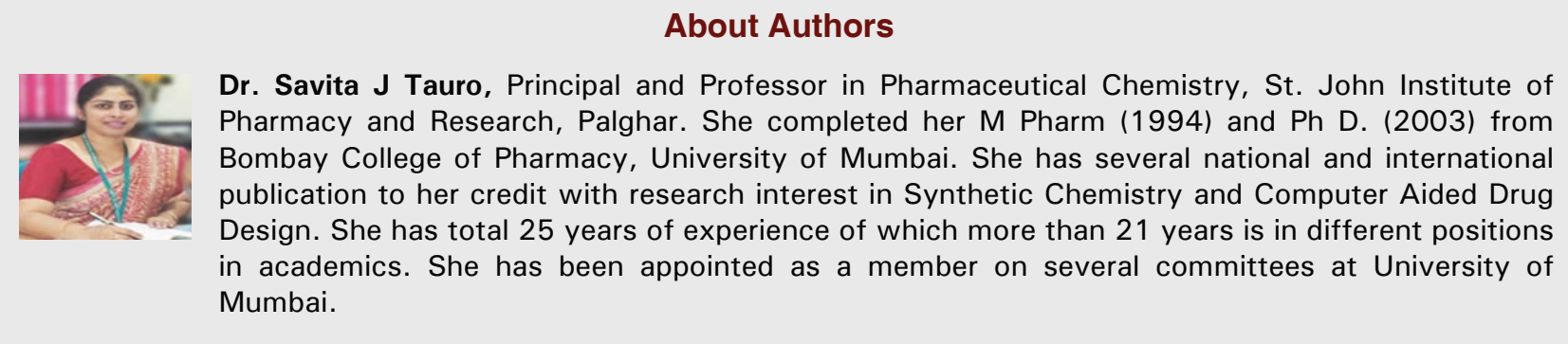




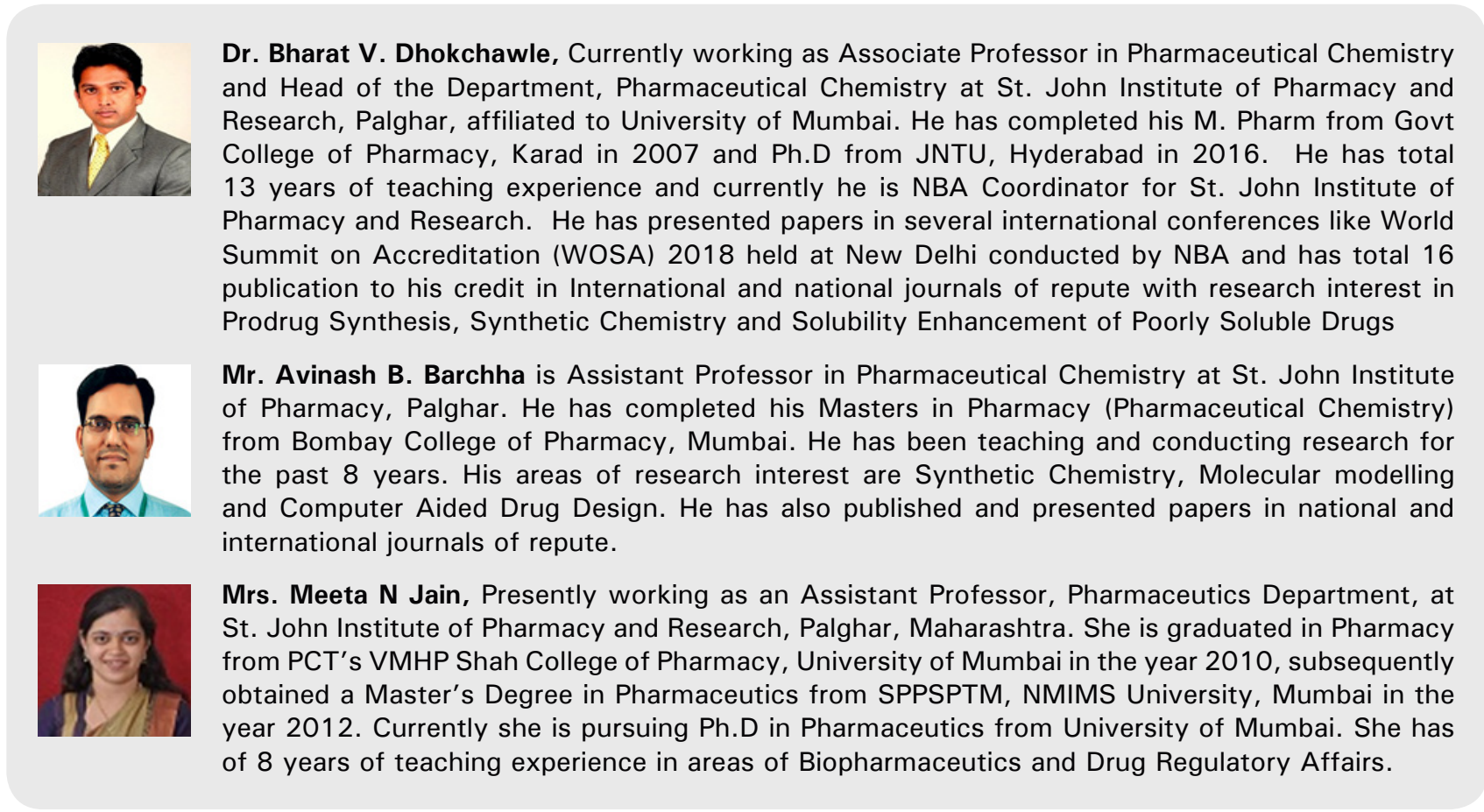

Cite this article: Tauro SJ, Dhokchawle BV, Barchha AB, Jain MN. An Approach to the Evaluation of Program Outcomes and Consideration of Activities beyond Curriculum for Improvement of Program Outcome Attainment. Indian J of Pharmaceutical Education and Research. 2020;54(4):896-904. 